\title{
Turkish-Russian cooperation: Implications for NATO
}

\author{
Karol Kujawa \\ Security Studies Department, WSB University, \\ Poland \\ kearol.knjawa@gmail@,com
}

ORCID 0000-0003-3035-0151

\begin{abstract}
The main objective of this article is to examine the factors that have influenced the rapprochement of economic and military relations between Turkey and Russia, especially in the years 2004-2021. This problem generates numerous research questions - who is the architect of this cooperation? Will Turkey completely limit its cooperation with Western partners, become more unpredictable and dependent on Russia? Or vice versa, will it seek to become a competitor of Russia in the international arena and in the region? From the methodological point of view, the author uses analytical, descriptive and comparative methods. The study uses both the discourse method and content analysis, including newspaper articles, television broadcasts, public speeches and other messages of individual politicians and intellectuals. The results of this research indicate that Russia is using Turkey as a tool to increase divisions within the NATO allies. Although Russian-Turkish ties have grown closer, in the recent years the countries have supported opposing sides in Syria, Libya, Ukraine, or Azerbaijan. However, Russia, which has significant leverage elements, benefits most from this rivalry. Russia supplies Turkey with natural gas and air defense missiles, builds a nuclear power plant and sends tourists to Turkey. In Syria, too, Russia can do great harm to Turkey.
\end{abstract}

Keywords: Turkey, Russia, NATO, MENA, security.

JEL Classification: B17, F42

$$
\begin{array}{r}
\text { Received: } \\
\text { September, 2020 } \\
\text { 1st Revision: } \\
\text { May, 2021 } \\
\text { Accepted: } \\
\text { June, 2021 } \\
\text { DOI: } \\
\text { 10.14254/2071- } \\
8330.2021 / 14-2 / 13
\end{array}
$$

\section{INTRODUCTION}

Russia-Turkey relations have been full of twists and turns. In the past, both the Ottoman Empire and Tsarist Russia saw each other as enemies. Both countries had imperial ambitions and wanted to play a key role in the Black Sea region. From the 17th to the 19th century, bilateral relations were dominated by armed conflicts. Even after the creation of the Turkish Republic, relations between the two countries did not develop properly. During Stalin's reign, the Soviets raised territorial claims against Turkey, which led 
to the country's rapprochement with the West. After World War II, Ankara began to see the USSR as a real threat to its own security. However, after Stalin's death and Turkey's accession to NATO, a change occurred. The Soviet Union adopted a more moderate stance towards the country: it stopped having territorial claims and officially recognized the new government in Turkey. After the end of the 1950s, the two states established economic cooperation. At the same time, Turkish President, Adnan Menderes, paid official visits to Moscow. However, all attempts to intensify cooperation between the two countries were interrupted by the Turkish army, which carried out a military coup and overthrew the democratically elected president (Kujawa, 2020; Kelkitli, 2017).

After the collapse of the Soviet Union, a new era in Turkish-Russian relations began. Russia continued to treat the post-Soviet area as its sphere of influence, while Turkey became a close ally of the USA and a rival of Russia in the Caucasus and Central Asia. It supported Azerbaijan and Turkish-language nations living in former Soviet republics. During the war in Nagorno-Karabakh the Russians supported Armenians and the Turks Azerbaijan. Also, during the Chechen wars, both countries stood on opposite sides. Russia accused the Turkish government of tolerating the activities of Chechen organizations and not responding to the creation of a safe haven for Caucasian fighters on Turkish territory. On the other hand, the Russian side supported the Kurdistan Workers' Party (PKK), which the Turkish authorities have fought against for years (Kortunov, 2005).

The warming in Turkish-Russian relations took place under the rule of the secular CHP party in the late 1990s. The Turkish authorities adopted a much more moderate stance towards Russia. As early as 1999, Turkey was the first NATO member to purchase weapons, helicopters and armored transporters from Russia. Also, Moscow fundamentally changed its perception of Turkey as a rival in the Caucasus and Central Asia. It began to treat Turkey as a partner. It stopped supporting the Kurdistan Workers' Party. Besides, in November 1999, Turkish Prime Minister Bülent Ecevit visited Moscow, and in October 2000, Russian Prime Minister Mikhail Kasyanov visited Turkey. As a result of these meetings, in 1999 Russia and Turkey signed a declaration on combating terrorism. In 2000 a joint committee for cooperation in the armaments industry was established, and in 2002 agreements on military cooperation were concluded (Bieleń, 2008; Aktürk, 2007).

The breakthrough in Turkish-Russian relations took place after the Justice and Development Party (AKP) came to power in Turkey in 2002. From that moment, we have witnessed a rapid revival in Turkish-Russian relations. Both countries have been are developing their economic and military cooperation and supporting each other internationally. However, this direction of Turkey's foreign policy concerns Western allies. They fear that the country will be completely dependent on Russia and thus become more unpredictable.

The main aim of this article is to examine the factors that have influenced the rapprochement of economic and military relations between these two countries, especially in the time period between 2002 and 2019. The author wonders what consequences this new alliance has for international security. And most importantly, will Turkey remain a member of NATO? Will Turkey completely reduce its cooperation with Western partners, become more unpredictable and dependent on Russia, or vice versa, Turkey will it seek to become more and more dependent on Russia and become a competitor of Russia in the international arena? Besides shedding new light on foreign policy, the author wonders whether leaders in Turkey and Russia might contribute to building long-term peaceful relations between the states and contribute to conflict resolution, or whether tension and violence between them will increase.

The author starts with, in section one, with the development of the Turkish-Russian relations under the AKP rule. Next chapter will concentrate on the Turkish-Russian relations after the coup attempt. Four stage will analyze a new tension between Turkey and Russia in Libya, Azerbaijan and Ukraine. Finally, I will describe perspectives of the bilateral relations. The discussion on the future prospects for mutual 
relations between Russia and Turkey is largely hypothetical. This analysis contributes to the discussion on the prospects for cooperation between Russia and Turkey.

\section{LITERATURE REVIEW}

In Poland, most researchers focus on the historical, sociological and cultural rather than the political aspect of Turkish-Russian relations (e.g. J. Wódka, Turecka polityka zagraniczna wobec Rosji od zimnowojennej konfrontacji do pragmatycznego partnerstwa, 2010). Such publications are undoubtedly a valuable contribution to global Turkish-Russian studies and can provide important support to ongoing research, but they do not fully exhaust the proposed subject matter. Other publications focus on the Russian-Turkish rivalry in a specific region (e.g. K. Strachota, Russia and Turkey: leading towards a concert of powers in Syria, 2017; K. Zasztowt, The South Caucasus in the Shadow of the Russian-Turkish Crisis, 2016). Very often, Russian-Turkish problems are also discussed in the EU context (e.g. A. Balcer, R. Sadowski, W. Paczyński, Turkey after the start of negotiations with the European Union - foreign relations and internal situation, 2007; A. Szymański, Turkey and Europe. Challenges and opportunities, 2012). Some, however, despite the fact that they deepen the knowledge on relations between these countries, require updating (e.g. M. Chudziak, The Russian-Turkish Relations Since 2002, 2014).

In foreign literature, Turkish-Russian relations are also often treated as a phenomenon of the past (e.g. S. Aktürk, Turkish-Russian Relations After the Cold War (1992-2002), Turkish Studies, 2007; H. Özdal H. S. Özertem, K. Has M. Demirtepe, Turkish-Russian Relations in the Post-Cold War Period: Current Dynamics, Future Prospects, 2013). One of the major works directly devoted to the analysis of Russo-Turkish relations was written by Fatma Kelkitli (Turkish-Russian Relations: Competition and Cooperation in Eurasia, 2017), or Ali Askerov (Contemporary Russo-Turkish Relations: From Crisis to Cooperation, 2018). All of these publications can be categorized as political science analyses, primarily concerned with the political dimension of Turkish aspirations in the region. While each of them undoubtedly constitutes a pillar of global Turkish-Russian studies, none of them addresses security issues and the future of NATO.

\section{METHODOLOGY}

Several research techniques have been used to analyze Turkish-Russian foreign and security policy. The first stage of the research included a library search, a thorough review of the recent literature on the research topic. Among the latter there are publications in scientific journals and books in English or Turkish. The second stage of the research focused on the analysis of existing sources in foreign languages, in particular official government documents. These include documents on Russian-Turkish relations, common foreign and security policy, as well as official documents of the Turkish state. In order to verify the research objectives in the third stage, the author confronted the preliminary assumptions with the opinions of experts during the Turkish Studies Symposium: "Turkey in the Aftermath of the Failed Coup Attempt" at the University of Illinois, Urbana-Champaign, US (June 20-23, 2017). Also, in the fourth stage of the research, author has conducted a field study was conducted in Turkey (Canakkale, Ankara, Istanbul). During the study tours interviews has been conducted with experts and government officials, think-tanks experts and academics from Turkey. In this way, the methodological principle of the case study, according to which it is necessary to obtain, through a wide range of research techniques, a comprehensive research material, all in order to conduct a reasonably complete and insightful analysis, has been fulfilled.

The results of these studies may prove very useful in the context of the ongoing academic debates surrounding the role of turkey in the region and what is its dynamics and the interest toward the Europe. 
Project may indicate what policies should be adopted by the western countries in relation to turkey. Besides, it is unlikely that future developments in the Middle East will lead to the end of the war in the region, and therefore this analytical work will remain important for many readers, including scholars, who want to broaden their knowledge and understand the role of turkey in international relations. The results of this work may help fill the gap.

\section{FIRST STAGE: AKP AND RUSSIA}

The breakthrough in bilateral relations took place after the Justice and Development Party (AKP) came to power in Turkey in 2002. Since then, Turkey has changed its foreign policy vectors. It has sought to increase its role in the region and develop cooperation with all its neighbors. Russia has played a particular role in this process. The Turkish authorities were well aware that without cooperation with Russia, it would be very difficult for them to achieve their goals. A new stage in relations between these countries began with the visit to Ankara of Russian President Vladimir Putin on 5-6 December 2004. Since then, regular meetings have been held between representatives of these countries. The Blue Stream pipeline, which was put into operation in 2005, was to become the foundation of cooperation between the countries. At the same time, Turkey did not want to limit its cooperation with Russia. Ankara began developing economic cooperation with Georgia and Azerbaijan. As a result, the Baku-Tbilisi-Ceyhan pipeline was commissioned in 2005 to supply oil from Azerbaijan to Turkish ports. At the same time, the construction of the Nabucco gas pipeline, backed by several European Union member states and by the United States, began. This project was to transport 31 billion cubic meters of gas annually from deposits in the Caspian Sea in Azerbaijan and Turkmenistan to an energy center in Austria. Moreover, in 2007, the Baku-Tbilisi-Erzurum gas pipeline was built to transport natural gas from the Shah Deniz gas field in Azerbaijan (Yildırım, 2013).

To sum up, in the first years of the AKP rule, Russia became a strategic partner in trade. However, Turkey did not want to limit its cooperation only with this country. Ankara's goal was to diversify its energy resources. To this end, Turkey had cooperated with other countries in the region and the European Union (Kanbur \& Bernat, 2013). Thanks to these projects, Turkey tightened its economic cooperation with Georgia and Azerbaijan, which tried to pursue a policy independent of Moscow.

\section{SECOND FIRST STAGE: 2010-2014}

The intensification of cooperation between Russia and Turkey took place in 2010-2014. One of the main architects of this policy was the Turkish Foreign Minister, Ahmet Davutoğlu. Initially, he was the chief advisor to the Prime Minister of Turkey, Recep Tayyip Erdoğan, and in 2009 he became the Foreign Minister of Turkey. Since the beginning of his diplomatic career, he has supported the policy of "no problems with our neighbors". He presented the main principles of this concept in his book entitled "Strategic depth" (Stratejik Derinlik). The book argues that:

1. Turkey's relations with its neighbors should be based on peace and security;

2. any obstacles that hinder the economic and cultural integration of the region should be removed;

3. Turkey has the task of becoming a regional superpower. Turkey has deep historical contacts with the Arabs, the Kurds, the Persians and geographical proximity to Central Asia, the Balkans and the Caucasus.

In his doctrine, however, Davutoğlu did not put Russia at first place. He claimed that good neighborhood policy with Russia is not an alternative to relations with the EU. Nor is the model partnership with the United States a rival partnership against Russia (Davutoğlu, 2010). 
The policy of the new minister led in a short time to the development of economic cooperation between Russia and Turkey. On 12 May 2010, during the official visit of Russian President Dmitry Medvedev to Turkey, an agreement on the introduction of visa-free travel between the two countries was signed. Both countries waived the visa requirement to enter the other country for a period of less than 30 days. Since then, the Turkish coast has been very popular with Russians. Every year several million tourists go to Turkey from Russia. In 2014, 4.5 million Russians visited Turkey. A new record was set four years later when nearly 6 million Russian tourists went to Turkey. In addition, it is estimated that there are currently over 300,000 mixed Russian-Turkish marriages in Turkey. In the seaside resorts you can easily buy Russian newspapers and watch Russian TV (Pinar, 2019; Nemtsova, 2019).

At the same time, Russia was becoming one of Turkey's most important trading partners. It imported mainly textiles, machinery, food and household appliances from Turkey and exported energy resources (see figure 1). Moreover, Turkey became Gazprom's second largest customer after Germany (23.4 billion cubic metres; 34.5 billion cubic metres, respectively) (Axmith, 2015). In 2011, Russian gas exports to Turkey were record-breaking at $25.8 \mathrm{bcm}$ (Enerji Gov, 2019). In addition, Russia implemented a number of strategic projects in Turkey. The construction of the first nuclear power plant in Turkey, in which the Russian corporation "Rosatom" is involved, is planned to be completed in 2023. The Russian side will remain the owner of the power plant, but has announced its willingness to surrender $49 \%$ of shares to Turkish or foreign investors (Schneider 2019; Özdal , Özertem, Has, Demirtepe, 2013).

Table 1

Level of trade and growth between Turkey and Russia in 2004-2016

\begin{tabular}{|c|c|c|}
\hline Years & Turkish exports to Russia (million \$) & Turkish imports from Russia (million \$) \\
\hline 2002 & 1168.30 & 3891.72 \\
\hline 2003 & 1367.59 & 5451.31 \\
\hline 2004 & 1859.18 & 9033.13 \\
\hline 2005 & 2377.04 & 12905.61 \\
\hline 2006 & 3237.61 & 23508.49 \\
\hline 2007 & $4720-26.85$ & 31364.47 \\
\hline 2008 & 6481.48 & 19718.96 \\
\hline 2009 & 3202.37 & 21599.56 \\
\hline 2010 & 4631.49 & 23952.93 \\
\hline 2011 & 5992.71 & 26625.02 \\
\hline 2012 & 6682.98 & 25064.21 \\
\hline 2013 & 6964.20 & 25293.39 \\
\hline 2014 & 5945.71 & \\
\hline
\end{tabular}

Source: TUİK 2019. (MFA Turkey, 2019; WITS, 2020).

Besides, after lengthy negotiations in 2012, the Turkish authorities agreed to the South Stream pipeline being laid through Turkish territorial waters. The project would allow Russians to transport 63 
bcm of gas from the Caspian Sea to countries in Central and Eastern Europe, Austria, Italy and Greece, bypassing traditional routes through Ukraine, Poland and Belarus (Turowski, 2019). The largest shareholders in this project are Russian energy giant Gazprom (50 per cent) and Italian Eni (20 per cent), while the French company EDF and German Wintershall each have a 15 per cent stake. The construction of the South Stream pipeline has been in conflict with the Nabucco pipeline project, supported by the European Union, which aims to reduce Europe's energy dependency on energy from Russia by transporting gas from the Caspian Sea to Europe via Turkey. The Nabucco project, supported by both the European Union and the United States, was to transport 31 billion cubic meters of gas annually from deposits in the Caspian Sea in Azerbaijan and Turkmenistan to an energy center in Austria. However, its construction never took place due to the financial crisis in the EU and the lack of political will of Western European countries.

Despite the fact that the two countries were seeking to intensify their economic cooperation, their interests in the region continued to differ. Their main dispute has been their policy towards Syria. The Kremlin was not as loyal an ally of Damascus as Tehran, and the survival of the Syrian government was still his priority. Russia wants to keep Assad in power because he is his most important ally in the Arab world. However, after the outbreak of the so-called Arab Spring in 2010, Prime Minister Recep Tayyip Erdoğan initially adopted a rather moderate course towards the Syrian president. At the same time, he tried to persuade Assad to carry out democratic reforms. Before the parliamentary elections in Turkey on 12 June 2011, in which the AKP party won, the Turkish Prime Minister became more critical of the regime. He called on the Syrian President to end his brutal actions against anti-government demonstrators. However, the bloody repression of demonstrations by security forces in Hama in the first days of August 2011 led Erdoğan to increase pressure on Syria. He announced that Assad could lose the support of Turkey if he did not stop the bloodshed and carry out reforms. However, the Turkish prime minister's requests were not answered (Kujawa, 2011).

\section{THIRD STAGE - CRISIS AND RECOVERY. TURKISH-RUSSIAN RELATIONS AFTER THE COUP ATTEMPT}

The growing crisis in the Middle East has put Turkish-Russian relations at a crossroads. In 2015, a Russian Su-24 plane was shot down by Turkish fighters over the Turkish-Syrian border. Moscow responded with sanctions. It banned the export of certain agricultural products, revoked visa-free travel for Turkish citizens, and imposed restrictions on Turkish businessmen. Sanctions did not cover the energy sector (Askerov, 2018). In the face of the crisis, Turkey decided to apologize for the incident and restore economic relations as soon as possible. The blame for the shooting down was placed on the Gülen movement. In order to remedy the damage caused by the aviation incident, both countries signed a joint declaration to lift all trade restrictions between the two countries. As a result, the losses slowly recovered. In 2017, the level of bilateral trade increased from 16.9 billion USD in 2016 to 22.3 billion USD (Iletisim, 2019).

Turkey has not only taken quick steps to restore good relations with Russia. It has also changed its policy towards Syria. Since then, Turkey has begun to relax its position towards the Assad regime: it has increasingly become more rare to demanded the departure of Assad (Strachota, 2017). The adoption of these foreign policy vectors by Turkey was welcomed by the Kremlin. Since then, Russia has begun to take an active part in the work for the stabilization of the Middle East. However, the crisis with Russia made the Turkish political elite aware of the threat posed by dependence on Russian energy resources. Since then, the Turkish authorities have made efforts to diversify their energy sources: in order to reduce Russia's monopoly on gas supplies, the construction of the Trans-Anatolian TANAP pipeline was 
launched in 2015, which will enable gas exports from the giant Shah Deniz fields in Azerbaijan to Europe. The project was inaugurated in 2018. The ceremony was attended by the President of Turkey, the President of Azerbaijan, Ilham Aliyev, the President of Ukraine, Petro Poroshenko, the President of Serbia, Aleksandar Vučić, and the Prime Minister of Bulgaria, Boyko Borisov. In the same year, the TransAtlantic Pipeline (TANAP) and the Trans-Adriatic Pipeline (TAP) along the banks of the Marica River on the Turkish-Greek border were joined. As a result of the connection of these two pipelines, natural gas from Azerbaijan can be transported to Italy (World Bulettin, 2019).

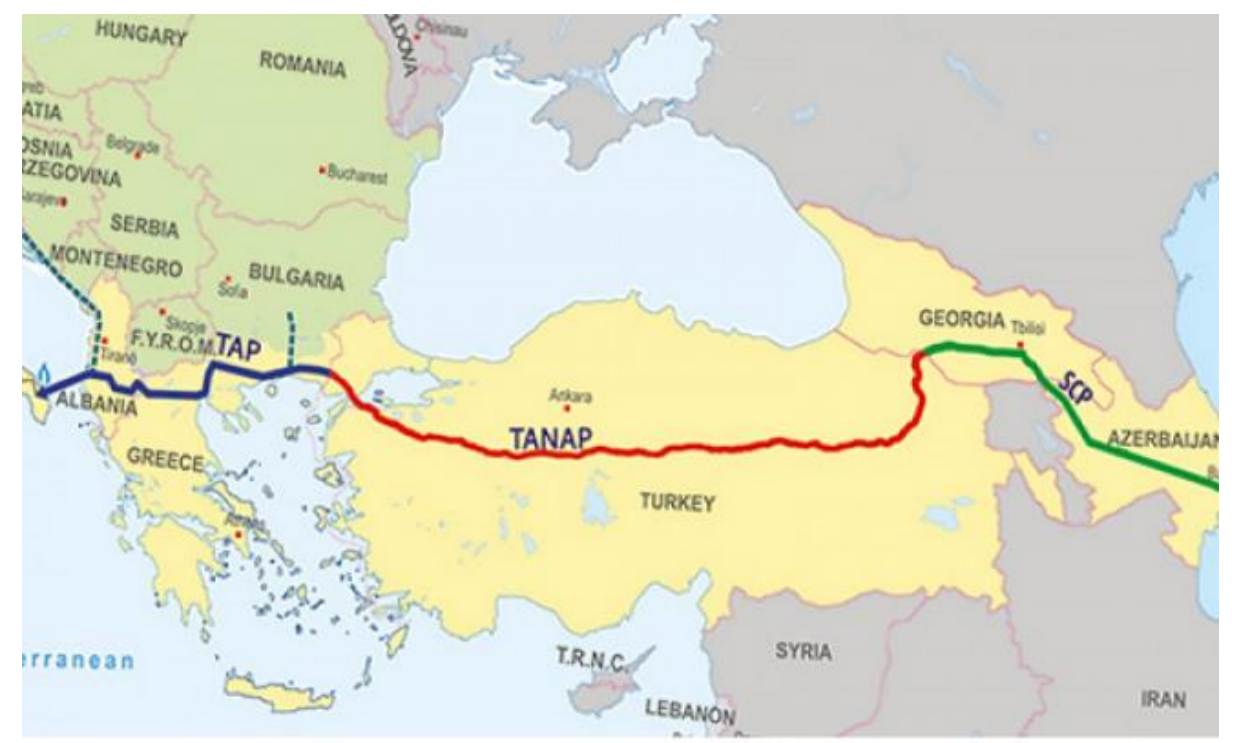

Figure 1. TANAP project vital for Turkey, Azerbaijan Source: World Bulettin, 2019.

Paradoxically, the internal situation in Turkey had the greatest impact on strengthening cooperation between these countries. In 2017, a military coup d'etat failed. As a result, thousands of people connected with the Gülen movement were arrested. The vast majority of Western European countries expressed their protest against the brutality of the Turkish authorities. Russia, in contrast, expressed its solidity and support for the President of Turkey. For years, the Russian authorities have regarded the Gülen movement as a threat to their internal security. It treated its supporters as an American 5th column. As early as in 2000, the Russian Federal Security Service (FSB) launched an investigation into Gülen-related institutions and educational centers. Three years later, some of Gülen's schools were closed down due to a "threat to national security" and school teachers were deported. In 2007, the Russian prosecutor ruled that the group's ideology was dangerous, and the sale of Gülen's books was banned. Eventually, in 2011, the Russian authorities closed all of Gülen's institutions on the territory of their country (Russia: The Fethullah... 2015).

This attitude of Putin towards the Gülen movement led Erdoğan to see him as an ally. From then on, the Turkish president began to recognize Russia as a guarantor of his interests. Russia has become not only a strategic economic ally for Turkey, but above all a military ally. Despite opposition from the United States, Turkey decided to purchase the Russian S 400 system. In mid-2019, the Turkish authorities announced that they intended to accept deliveries of the S-400 system from Russia. The Turkish president stated that he would not withdraw from purchasing Russian weapons. As a result, Russia started to supply S-400 systems, and the training of Turkish soldiers in handling Russian weapons has already been completed. 
Moreover, in order to avoid misunderstandings, Russia, Turkey and Iran very often started organizing meetings within the framework of the so-called "Astana Three", during which they consulted each other on the most important decisions concerning the future of the Middle East. One of the most important of these was the issue of Syria. However, the interests of these countries were not always consistent. The Turkish authorities do not want at all costs to allow the emergence of a Kurdish quasi state in northern Syria through which a pipeline connecting the region with oil and gas-rich northern Iraq could be built in the future. They are striving to create a so-called 'safety zone' in the region, to which some 3 million Syrian refugees are to be resettled. To achieve this goal, the Turkish authorities carried out a military operation, "Source of Peace", in October 2019. They wanted to create a $30 \mathrm{~km}$-wide strip for a so-called "safety zone" in northern Syria, and to force the Kurds living there associated with the General Protection Units (YPG) to leave the area. The Russian authorities reacted critically to these actions, claiming that they violated the territorial integrity of the country.

However, the dispute between the allies was quickly resolved. Russia agreed to Turkish conditions. This happened during a meeting between the Russian and Turkish presidents in Sochi. A 32-kilometrewide buffer zone will be set up in Syria, joint patrols of Turkish and Russian soldiers have been launched in the area, and Kurdish fighters will be removed as a result. In this way, the northern part of Syria, hitherto controlled by the Kurds, will be under the rule of the Turks, Russians and the Syrian government army. In place of the Kurds, Turkey is to resettle the more than 3.5 million Syrian refugees it has hosted so far.

\section{ETHNIC DIVISIONS IN NORTHERN SYRIA}

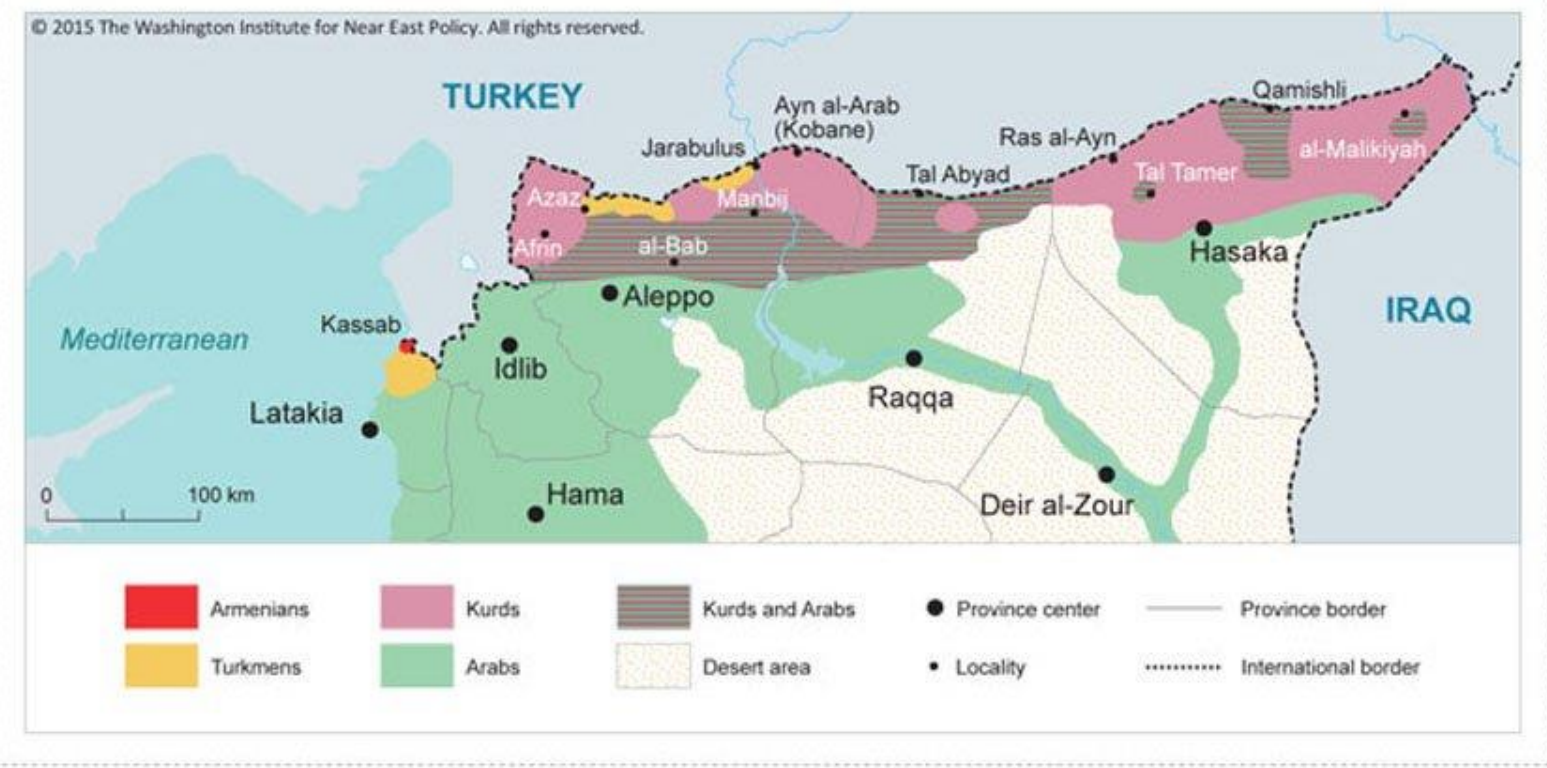

Figure 2. Ethnic divisions in Northern Syria

Source: Washington Institute, 2019.

The Sochi agreement has proved extremely beneficial for Turkey. The main threat to Turkey - the prospect of a Kurdish state in the northern part of Syria - has been removed. Moreover, the problem of refugees from Syria, who are a growing problem for Turkey, is to be resolved. Their growing number is affecting the popularity of the Turkish president. The first sign of this was felt during the recent local elections, in which the ruling AKP party lost two million of supporters. 


\section{SEVENTH STAGE: A NEW TENSION BETWEEN TURKEY AND RUSSIA.}

\section{THE CASE OF LIBYA}

Cooperation between Turkey and Russia has not been as good as in Syria in other parts of the world. Libya has become another theater of rivalry between the countries. In late 2019, Turkey began supporting the UN-recognized western-based Government of National Accord (GNA) in Tripoli. Despite an arms embargo on Libya by the United Nations, Ankara has supplied drones and air defense to GNA. It has also decided to send its military trainers, planners, and Syrian mercenaries. On the other hand, the eastern Libyan forces allied with Field Marshal Khalifa Haftar have received support from the United Arab Emirates, Egypt, France, and Russia. Moscow provided the necessary advanced weaponry and personnel to operate them. It also provided a Pantsir-type air defense system. The Wagner Group (troops of a proKremlin private security firm) and Su-24 fighter jets were also flown to Libya. The deployment of Russian forces halted the Tripoli government's counteroffensive supported by Turkey. The conflict has since died down and there are no significant territorial changes (Wintour, 2020).

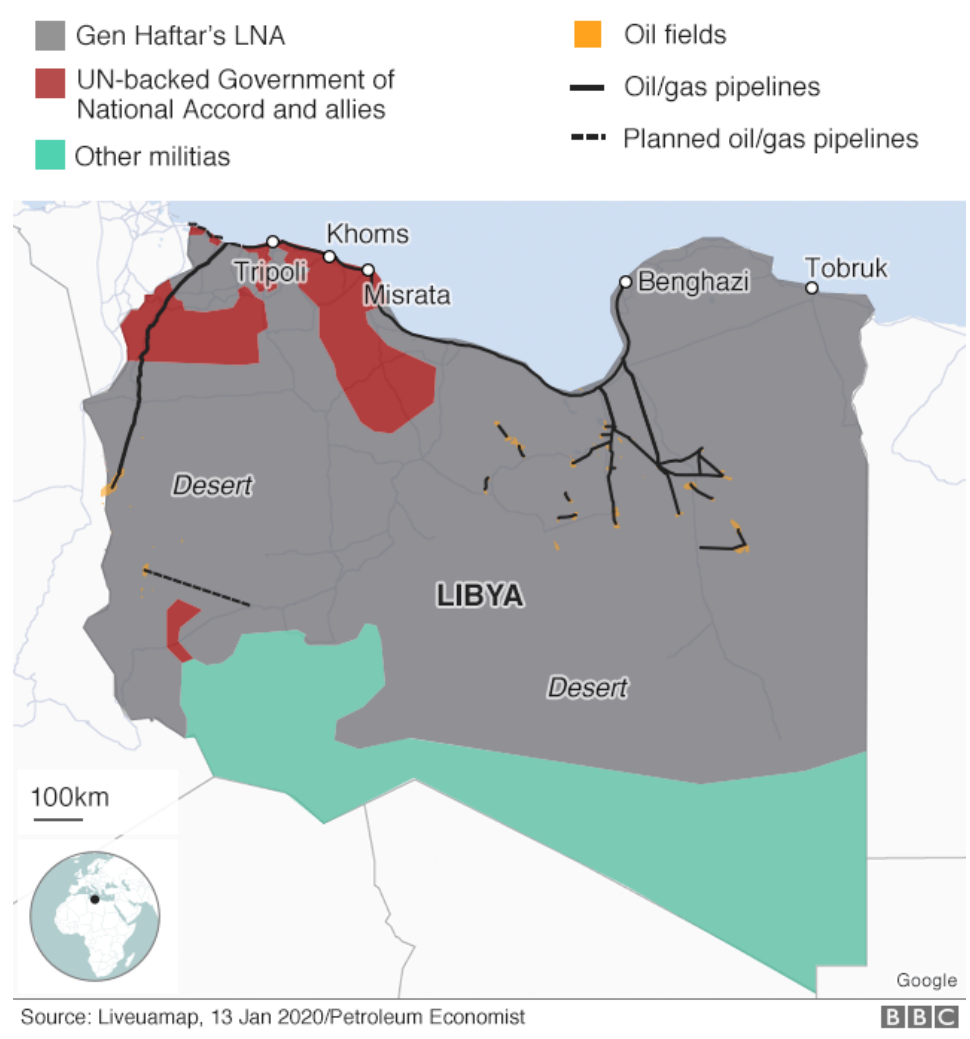

Figure 3. Libya

Source: BBC, 2020.

Russia perceives Libya as the "soft underbelly" of Europe. Therefore, the presence of the Russian armed forces in North Africa will undoubtedly give Russia a much stronger grip on the European Union and may deepen its influence in the MENA region. Moreover, Libya has long been one of Russia's most important economic partners among the Arab states. Moscow hopes that the new Libyan authorities will help it develop economic and energy cooperation and will implement contracts concluded before the 
outbreak of the civil war. Libya's energy resources and the presence of several deep-sea ports will give Putin a logistical and geostrategic advantage.

Turkey, on the other hand, has never had such good relations with Libya as Russia. Therefore, she saw the overthrow of Gaddafi as an opportunity to increase her influence in this country, but also in the eastern Mediterranean region. It supported the government forces in Tripoli, on the one hand, was to prevent Libya from falling under the influence of Egypt and the United Arab Emirates. Another reason for Turkey's involvement in Libya was due to economic factors. Ankara counted on an agreement to mark a sea border with Libya. In this way, it would be able to freely exploit the natural deposits from the bottom of the Mediterranean Sea. The aid provided to the government allowed Ankara to also establish an airbase in Libya. In this way, Turkey will have greater influence in the Mediterranean Sea.

\section{THE CASE OF AZERBAIJAN}

Azerbaijan has also become a new theater of rivalry between these countries. For years, Turkey has supported this country on the basis of cultural ties and shared geopolitical aspirations. An important factor influencing the foreign policy of the Turkish Republic is the Pan-Turkism ideology, proclaiming the ethnic unity of the Turkish peoples and the need for their cultural and political integration, from the Bosphorus Strait to the Altai Mountains (Zasztowt, 2016). Both countries share not only ethnic and linguistic ties, but also strong economic ties. In recent years, Azerbaijan has gradually become the main gas supplier to Turkey. In the first half of 2020, Turkey imported 20.4\% more cubic meters of Azerbaijani gas than in the corresponding period of 2019. Meanwhile, gas imports from Russia fell by almost $62 \%$ compared to the same month in 2019. In May 2020, Azerbaijan officially became the main gas supplier to Turkey (Avdaliani 2020). This was made possible after the launch of TANAP in late 2019. The \$6.5 billion project is part of the $\$ 40$ billion Southern Gas Corridor, a network of pipelines connecting Azerbaijan's Shah Deniz II fields with the vast European market. Over the past few years, there has also been a trend toward deeper military cooperation. In 2010, Turkey and Azerbaijan signed a Strategic Partnership and Mutual Assistance Agreement. In addition to joint military exercises, the treaty stipulates that the signatories will assist each other "by all possible means." Joint military exercises were held in Baku, Nakhchivan, Ganja, Kurdamir and Yevlakh (Huseynov, 2020).

Turkey's increased support for Azerbaijan was particularly evident in the war between Azerbaijan and Armenia in Upper Karabakh in September and October 2020. In that conflict, Turkey provided both diplomatic and military support to Azerbaijan. Soon after the first borderline clashes erupted, Turkey sent 11,000 troops to Azerbaijan for joint exercises: Turkish drones spearheaded attacks on Azerbaijan, and Ankara likely provided the infrastructure and support for these weapons. Turkey was also accused of sending Syrian fighters to Nagorno-Karabakh to support Azerbaijani forces.

After six weeks of bloody fighting, a declaration to end hostilities was signed by Azerbaijani President Ilham Aliyev and Armenian Prime Minister Nikol Pashinyan. Russian President Vladimir Putin also signed the document. According to it, the parties retain the "positions held by each other," with NagornoKarabakh losing territories to Azerbaijan. Under the truce agreement, Russian peacekeepers were deployed along the front lines in Nagorno-Karabakh and in the corridor between that enclave and Armenia. 


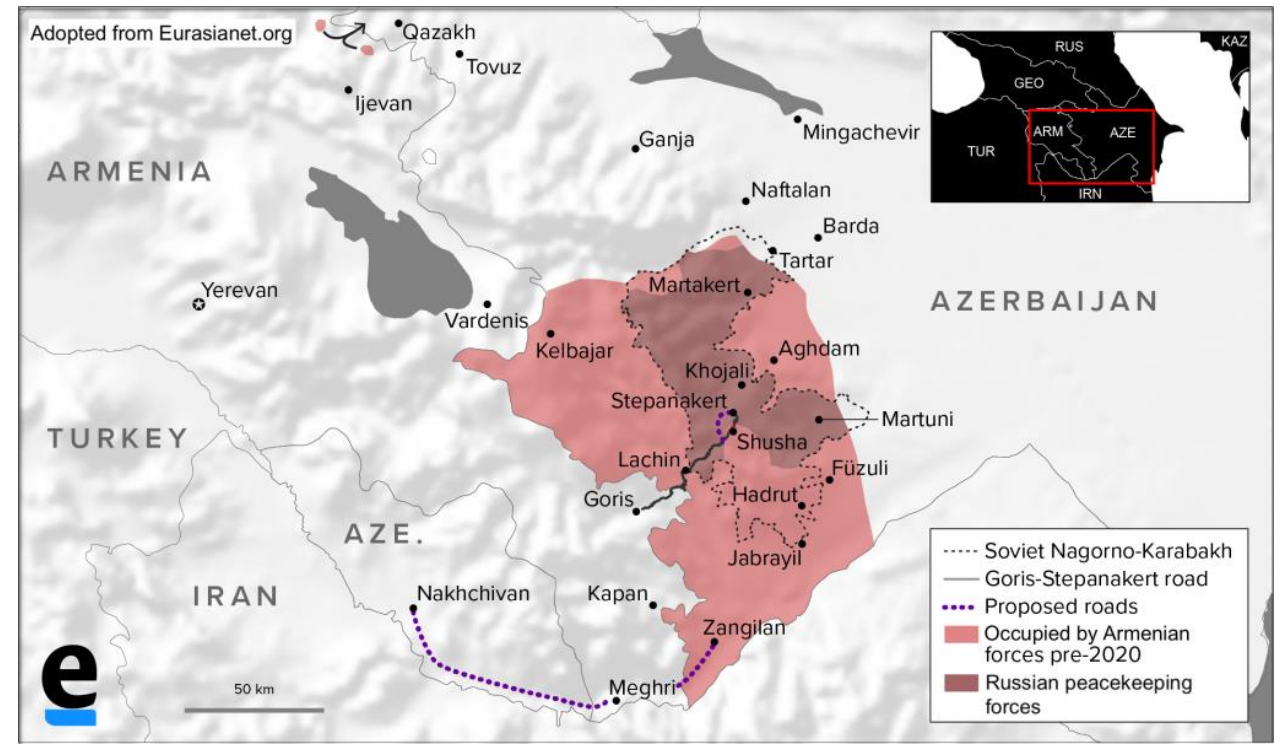

Figure 4. 2020 Nagorno-Karabakh ceasefire agreement

Source: Caspian Policy, 2021.

Moscow was the biggest beneficiary of this agreement. The Kremlin achieved a number of key objectives. First of all, as a result of the peace agreement, Russia increased its influence in the region. By deploying peacekeepers, Russia has separated the two adversaries and will patrol the corridor connecting Armenia to Nagorno-Karabakh. Russia had been seeking this since 1994, but could not get a war at the negotiating table before then. In this way, Russia has not only secured a military foothold in Azerbaijan, but can also influence natural gas sales to Turkey and European markets. The TANAP pipeline infrastructure is located near the stationing of Russian soldiers. This increases the risk of stability of supply and does not serve the interests of energy producers and consumers. Second, as a result of Armenia losing the conflict, pro-Western forces in the country have been weakened. In 2018, as a result of the democratic revolution in Armenia, Nikola Pashinyan, who is perceived as an enemy in Russia, came to power. His concessions in the conflict have seriously weakened his position in the country and created an opportunity for a much more pro-Russian leader to take power in Yerevan.

In turn, Turkey's involvement in the Nagorno-Karabakh conflict was primarily aimed at gaining an advantage over Moscow and potentially replacing Russia as the key patron of Azerbaijan. However, this task has not been achieved by the Turkish president. Russian troops will be the only peacekeepers monitoring the implementation of the agreement, without Turkish troops. The Kremlin has denied Turkey any military presence in Nagorno-Karabakh despite earlier Turkish military support that tipped the scale of Azerbaijan's superiority on the ground. Turkey's involvement in the conflict in the Caucasus, however, has helped divert public attention from the importance of the important economic problems facing Turkey.

\section{THE CASE OF UKRAINE}

Another area where Russian and Turkish interests clash is Ukraine. In recent years, Turkey has become a very reliable strategic partner of Ukraine. It openly supports Ukraine's accession to NATO. The Turkish president has also condemned Russia's annexation of Crimea and is standing up for the Crimean Tatars, whose political representatives are being persecuted by the Russian government on the peninsula. Turkey is also troubled by reports that Russia has blocked the Kerch Strait, which connects the 
Black Sea to the Sea of Azov, for six months. Ukraine is also working with Turkey to return Turkish opposition figures who have fled the country to Ankara. The two countries also intend to conclude a free trade agreement. Turkey and Ukraine are also deepening military cooperation.

To this end, Ukraine signed an agreement with Turkey for the purchase of Bayraktar TB-2 drones, which helped decide the fate of the conflicts in Syria, Libya and Nagorno-Karabakh. Drones we ordered by Ukraine in January 2019 and the first delivery took place in June of that same year now after nearly two years of training the UAVS now operational and were used in a reconnaissance mission over the Donbass region (Tastekin 2020). However the intensification of cooperation by Ukraine and Turkey is not well perceived by Russia. In reaction Russian minister of foreign affairs Lavrow warned Turkey against facilitating military tendencies of Ukraine. Shortly following the Erdoğan Zelensky talks Russia banned all tourist flights to Turkey in an apparent blow to the country's recreation industry. Formal clamed to move is due to worsening situation in Turkey with the COVID 19 in Turkey.

\section{CONCLUSION}

Turkish-Russian relations resemble a sinusoid and are based on successive phases of rivalry and cooperation. In recent years, Turkey has regarded Russia as an alternative to its Western allies. Unlike them, Moscow has not interfered with internal affairs and expressed strong support for the Turkish president during the failed coup in 2016. Intensifying military or economic cooperation with Russia does not mean that Turkey will become completely dependent on that country. Turkey's goal is to increase its role on the international stage. To achieve this goal, it wants to become independent from Russian gas. Recently, Turkish authorities have become increasingly aware of the threat posed by dependence on gas supplies from Russia and have been making efforts to diversify their energy sources. One solution is the construction of the TANAP gas pipeline to transport gas from Azerbaijan to Turkey and on to Europe. This multi-sectoral policy may contribute to Turkey's energy security.

Russia, in turn, views Turkey as a key element in its efforts to weaken NATO. Its goal is to exclude Turkey from the North Atlantic Alliance structures, close NATO bases and withdraw American soldiers from the country. But will this be achieved? On the one hand, it seems unlikely. The vast majority of Turks still express the need to remain in NATO. Besides, Turkey's exit from NATO would significantly reduce the country's defense capabilities. Without modern technology, it will be very difficult for Turkey to conduct operations against the PKK and other terrorist organizations in Iraq and Syria.

It seems, however, that under Erdoğan there will be no major changes in the country's foreign policy. He will strive at all costs to maintain close relations with Putin, who supports his position in the country and does not interfere in internal affairs. Only after the Turkish president leaves power can a reset in relations with the West occur. Moreover, within his party, the AKP is increasingly dissatisfied with Erdoğan's past policies. There are still many Western supporters within its ranks who are increasingly bold in their criticism of Turkey's foreign policy vectors. The opposition, which seeks to democratize Turkey and draw closer to the European Union, is also growing in strength. Their chances of taking power in the coming years are slim, but in the long run their position will steadily grow. The last local elections showed that Erdoğan is systematically losing supporters (about two million). In addition, the economic crisis has caused more and more Turks to express their disappointment with the president's policy and want him to leave. Therefore, it is unlikely that Turkey will leave or be kicked out of NATO, despite the fact that such voices are increasingly heard in Turkish parliament as well as in the US Congress. In this situation, Turkey has significantly weakened its position. Therefore, in spite of these difficulties and problems, Turkey will be jockeying between NATO and Russia to gain as much benefit for itself as possible. 


\section{ACKNOWLEDGEMENT}

The authors are thankful to the Kosciuszko Foundation in New York for financial support to carry out this research at the Russian, East European, and Eurasian Center (REEEC), University of Illinois, Urbana-Champaign, US.

\section{REFERENCES}

Aktürk, Ş. (2007) Turkish-Russian Relations After the Cold War (1992-2002), Turkish Studies, 7 (3), 337-364.

Askerov, A. (Ed.). (2018). Contemporary Russo-Turkish Relations: From Crisis to Cooperation, Lexington, London, 65-70.

Avdaliani, E. (2020). Azerbaijan Becomes Turkey's Top Gas Supplier. Retrieved from https://modern diplomacy.eu/2020/08/21/azerbaijan-becomes-turkeys-top-gas-supplier/ (2.02.2021).

Axmith, B. (2015). Denying History: The United States' Policies Toward Russia in the Caspian, 1991-2001, Hamburg, 121.

Baczynska, G. (2019). Putin opens Moscow's largest mosque, warns against extremists. Retrieved from: https://www.reuters.com/article/us-russia-mosque-idUSKCN0RN1UD20150923 (8.08.2019).

BBC, Libya crisis: Rival authorities announce ceasefire (21 August 2020). Retrieved from: https://www.bbc.com/news/world-africa-53863627 (10.01.2021).

Biznesalert (2016). Gdzie gaz z South Stream nie mógł, tam Moskwa pośle go przez Nord Stream. Retrieved from: https://biznesalert.pl/gdzie-gaz-z-south-stream-nie-mogl-tam-moskwa-posle-go-przez-nord-stream-2/ (8.08.2019).

Caspian Policy, The Nagorno-Karabakh Peace Deal: Reading Between the Lines (Nov 16, 2020). Retrieved from: https://www.caspianpolicy.org/the-nagorno-karabakh-peace-deal-reading-between-the-lines

Davutoğlu, A. (2010). Turkey's Zero-Problems Foreign Policy, Foreign Policy, Retrieved from https:/ foreignpolicy.com/2010/05/20/turkeys-zero-problems-foreign-policy/(8.08.2019).

Enerji Gov (2019). Natural Gas Pipelines and Projects. Retrieved from https//enerji.gov.tr/enUS/Pages/NaturalGas-Pipelines-and-Projects (8.08.2019). Ethnic divisions in Northern Syria, Retrieved from: http://static3.businessinsider.com/image/56165f7abd86ef1b008c038c-840-463/pyd.jpg (10.08.2019).

Iletisim (2019). We aim to increase the bilateral trade volume between Turkey and Russia to 100 billion, Presidency of the Republic of Turkey, Directorate of Communications. Retrieved from: https://www.iletisim.gov.tr/English/haberler/detay/we-aim-to-increase-the-bilateral-trade-volume-betweenturkey-and-russia-to-100-billion (8.08.2019).

Kanbur, M., \& Bernat, T. (2013). Europeanization in Turkey and accession process to the European Union. Journal of International Studies, 6(2), 79-93. doi:10.14254/2071-8330.2013/6-2/7.

Kelkitli, F. (2017). Turkish-Russian Relations: Competition and Cooperation in Eurasia, London, Routledge.

Kujawa, K. (2011). Turkey and the Crisis in Syria, Bulletin. The Polish Institute of International Affairs, 63 (277), Warszawa 2011. Retrieved from: http://www.pism.pl/index/?id=316282ddb77e11b0b58c60ed59b1e308 (8.08.2019).

Kujawa K. (2020). Turkey and Russia in the Global Order. Implications for the Central and Eastern Europe, IBIMA Conference, Retrieved from: https://ibima.org/accepted-paper/turkey-and-russia-in-the-global-orderimplications-for-the-central-and-eastern-europe/(02.03.2021).

Leal-Arcas, R., Grasso, C. (2015). The European Union and its energy security challenges. Engagement through and with networks. Retrieved from: https://www.researchgate.net/figure/Nabucco-and-South-Stream-PipelineProjects_fig1_269402180(10.08.2019).

MFA Turkey (2019). Turkey's commercial and economic relations with Russian federation. Retrieved from: www.mfa.gov.tr/turkey s-commercial-and-economic-relations-with-russian-federation.en.mfa (8.08.2019)

Nemtsova, A. (2019). From Russia with love, thousands of wives for Turkish husbands. Retrieved from https://www.thedailybeast.com/from-russia-with-love-thousands-ofwives-for-turkish-husbands (01.09.2019).

Özdal, H., Özertem, S., Has, K. \& Demirtepe, M. (2013). Turkish-Russian Relations in the Post-Cold War Period: Current Dynamics, Future Prospects, US AK Report, 13, 6, 47-52. 
Pinar, B. (2019). Turcja traci turystów przez politykę. W ciagu dwóch lat ich liczba spadła o 16 milionów. Retrieved from: wyborcza.pl/7,75399,22009657,turcja-traci-turystow-przez-w-ciagu-dwoch-lat-ich.html (8.08.2019)

Refworld (2015). Russia: The Fethullah Gülen movement (Hizmet movement), including activities and regions of operation; treatment of members by society and authorities; recourse available to members, including state protection. Retrieved from: https://www.refworld.org/docid/ 56b06aa24.html (8.08.2019).

Schneider, M. \& Froggatt, A. (2019), The Current Status of the World Nuclear Industry. The Technological and Economic Future of Nuclear Power, ed. Reinhard Haas, Lutz Mez, Amela, New York, 62.

Strachota, K. (2017). Rosja i Turcja: przymiarki do koncertu mocarstw w Syrii, OSW. Retrieved from: https://www.osw.waw.pl/pl/publikacje/analizy/2017-01-04/rosja-i-turcja-przymiarki-do-koncertu-mocarstww-syrii (10.02.2021).

Tur-info (2019). Turcja przyjęła rekordową liczbę turystów. Retrieved from: www.tur-info.pl/a/59787,turcjaturystyka-atak-terrorystyczny.html (10.08.2019).

Turowski, P. (2019). South Stream - odpowiedź na potrzeby rynku czy narzędzie polityki zagranicznej?. Retrieved from: https://www.bbn.gov.pl (8.08.2019).

Washington Institute. (2019). Retrieved from: https://www.washingtoninstitute.org/uploads/Documents/pubs/SyriaAtlasCOMPLETE-3.pdf

Wintour, F. (2020). Will Turkish drones help Ukraine reclaim territory? Retrieved from: https://www.theguardian.com/world/2020/oct/05/turkey-and-russia-deepening-roles-in-libya-complicatepeace-efforts (03.03.2021).

WITS (2020). Turkey trade balance, exports and imports by country and region 2014. Retrieved from: https://wits.worldbank.org/CountryProfile/en/Country/TUR/Year/2014/TradeFlow/EXPIMP (10.02.2021).

Worldbulletin (2019). TANAP project vital for Turkey, Azerbaijan. Retrieved from: https://www.worldbulletin.net/turkey/tanap-project-vital-for-turkey-azerbaijan-h203891.html (10.08.2019).

Yildırım, T. (2013). Turkey's place in the path of the development of common energy politics of the European Union. Journal of International Studies, 6(2). Received from: https://www.jois.eu/?139, en turkey's-place-in-thepath-of-the-development-of-common-energy-politics-of-the-european-union (9.09.2013).

Zasztowt, K. (2016). The South Caucasus in the Shadow of the Russian-Turkish Crisis. PISM Bulletin, 14(864). Retrieved from: www.pism.pl/publications/The South Caucasus in the Shadow of the Russian_Turkish _Crisis (03.03.2021). 